\title{
Common Structural Features in Calcium Hydroxyphosphonoacetates. A High-Throughput Screening
}

\author{
Rosario M. P. Colodrero, ${ }^{\perp}$ Aurelio Cabeza, ${ }^{\perp}$ Pascual Olivera-Pastor, ${ }^{\perp}$ Maria Papadaki, ${ }^{\ddagger}$ Jordi Rius, ${ }^{\#}$ \\ Duane Choquesillo-Lazarte, ${ }^{\ddagger}$ Juan M. García-Ruiz, ${ }^{\ddagger}$ Konstantinos D. Demadis, ${ }^{¥}$ and Miguel A. G. Aranda ${ }^{*, \perp}$ \\ ${ }^{\perp}$ Departamento de Química Inorgánica, Universidad de Málaga, Campus Teatinos S/N, 29071-Málaga, Spain \\ ${ }^{¥}$ Crystal Engineering, Growth and Design Laboratory, Department of Chemistry, University of Crete, Voutes Campus, Crete GR-71003, \\ Greece \\ \#Institut de Ciència de Materials de Barcelona, 08193 Bellaterra, Catalunya, Spain \\ ${ }^{\ddagger}$ Laboratorio de Estudios Crystalográficos, IACT, CSIC-Universidad de Granada, 18100 Granada, Spain
}

Supporting Information

\begin{abstract}
R, S$-Hydroxyphosphonoacetic acid $\left(\mathrm{H}_{3} \mathrm{HPA}\right)$ is an inexpensive multidentate organic ligand widely used for the preparation of organo-inorganic hybrid materials. There are reports of several crystal structures and the variability of the resulting frameworks is strikingly high, in contrast with the simplicity of the ligand. In an attempt to investigate and rationalize some salient structural features of the crystal structures, we have carried out a systematic high-throughput study of the reaction of $\mathrm{H}_{3} \mathrm{HPA}$ with $\mathrm{Ca}^{2+}$ in aqueous solutions ( $\mathrm{pH}$ values ranging $1.0-7.5)$ at room temperature and hydrothermally at $180^{\circ} \mathrm{C}$. The tested synthetic conditions yielded five crystalline singlephase $\mathrm{Ca}-\mathrm{H}_{3} \mathrm{HPA}$ hybrids: $\mathrm{Ca}_{3}\left(\mathrm{O}_{3} \mathrm{PCHOHCOO}\right)_{2} \cdot 14 \mathrm{H}_{2} \mathrm{O}$

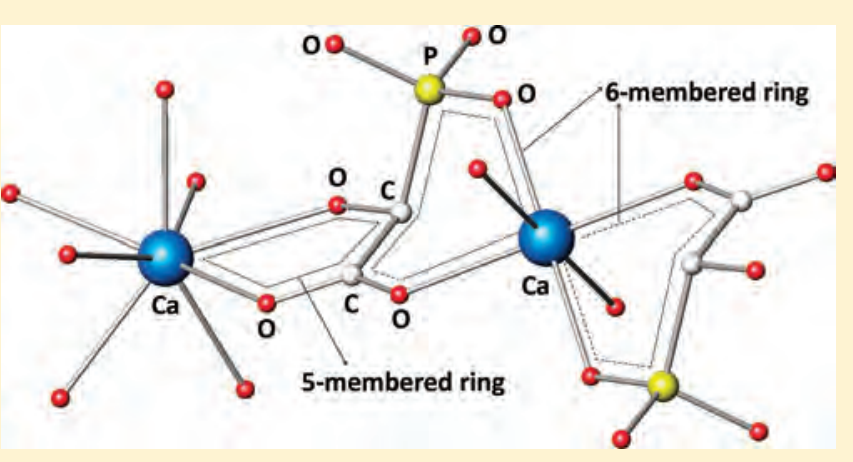
(1), $\mathrm{Ca}\left(\mathrm{HO}_{3} \mathrm{PCHOHCOO}\right) \cdot 3 \mathrm{H}_{2} \mathrm{O}(2), \mathrm{Ca}_{5}\left(\mathrm{O}_{3} \mathrm{PCHOHCOO}\right)_{2}\left(\mathrm{HO}_{3} \mathrm{PCHOHCOO}\right)_{2} \cdot 6 \mathrm{H}_{2} \mathrm{O}(3), \mathrm{CaLi}\left(\mathrm{O}_{3} \mathrm{PCHOHCOO}\right)(4)$, and $\mathrm{Ca}_{2} \mathrm{Na}\left(\mathrm{O}_{3} \mathrm{PCHOHCOO}\right)\left(\mathrm{HO}_{3} \mathrm{PCHOHCOO}\right) \cdot 1.5 \mathrm{H}_{2} \mathrm{O}(\mathbf{5})$. Four new crystal structures, $2-\mathbf{5}$, are reported (three from powder diffraction data and one from single-crystal data), which allowed us to unravel some key common structural features. The $\mathrm{Ca}-\mathrm{H}_{3} \mathrm{HPA}$ hybrids without an extra alkaline cation, 1-3, contain a common structural motif, which has been identified as a linear $\mathrm{Ca}-\mathrm{H}_{3} \mathrm{HPA}-\mathrm{Ca}-\mathrm{H}_{3} \mathrm{HPA}-\mathrm{Ca}$ trimer. This inorganic motif has a central $\mathrm{Ca}^{2+}$ in a distorted octahedral environment, whereas the two side $\mathrm{Ca}^{2+}$ cations are in an eight-coordinated oxygen-rich environment. The $\mathrm{H}_{3} \mathrm{HPA}$ ligands are chelating the central Ca ${ }^{2+}$ through two pairs of carboxylate and phosphonate oxygen atoms forming six-membered rings, $\mathrm{Ca}-\mathrm{O}-\mathrm{C}-\mathrm{C}-\mathrm{P}-\mathrm{O}-\mathrm{Ca}$. This coordination mode allows the peripheral $\mathrm{Ca}$ (II) ions to bind the ligand through the $-\mathrm{OH}$ group and the other carboxylate oxygen, forming a fivemembered ring, $\mathrm{Ca}-\mathrm{O}-\mathrm{C}-\mathrm{C}-\mathrm{O}-\mathrm{Ca}$. The presence of alkaline cations, $\mathrm{Li}^{+}$and $\mathrm{Na}^{+}$, disrupt this common structural feature leading to highly dense frameworks. Finally, similarities (and differences) between $\mathrm{Ca}-\mathrm{H}_{3} \mathrm{HPA}$ and $\mathrm{Cd}-\mathrm{H}_{3} \mathrm{HPA}$ hybrids are also discussed.
\end{abstract}

\section{INTRODUCTION}

Coordination polymers, also known as metal-organic frameworks (MOFs), are an important class of hybrid frameworks, in which polyfunctional organic molecules bridge metal cations (or clusters) into extended arrays. ${ }^{1}$ These materials exhibit a wide structural diversity chiefly as a result of the coordination preferences of the metal and the various ways in which the ligand can coordinate to the metal ion. ${ }^{1}$ Various aspects of hybrid materials have been recently reviewed. ${ }^{2}$ The possibility of designing materials with predetermined functionalities ${ }^{3}$ has prompted investigations of diverse applications for these hybrid systems, including gas separation ${ }^{4}$ and storage, ${ }^{5}$ heterogeneous catalysis, ${ }^{6}$ and photoluminescence. ${ }^{7}$

A particular class of multidentate ligands are polyfunctional phosphonic acids, having multiple oxygen-donor groups (and occasionally other groups) capable of binding a number of metal ions into structurally versatile metal phosphonate hybrids. ${ }^{8}$ Among these phosphonic acids, 2-hydroxyphosphonoacetic acid $\left(\mathrm{H}_{3} \mathrm{HPA}\right.$, where $\mathrm{H}_{3}$ stands for the number of exchangeable protons and HPA is the acronym of the acid) is a polyvalent ligand, bearing three different coordination groups $(-\mathrm{OH}$, $-\mathrm{COOH}$, and $-\mathrm{PO}_{3} \mathrm{H}_{2}$ ), that recently has attracted considerable attention as for the synthesis of metal phosphonates. ${ }^{9}$ In addition to being a stable and cost-effective compound, $\mathrm{H}_{3} \mathrm{HPA}$ also possesses a chiral carbon in its backbone for potential chiral separations and nonlinear optical applications. ${ }^{10}$ Some metal- $\mathrm{H}_{3} \mathrm{HPA}$ hybrids also exhibit anticorrosion, ${ }^{11}$ catalytic, $^{12}$ and photoluminescent capabilities. ${ }^{13}$

Received: December 13, 2010

Revised: February 14, 2011

Published: March 11, 2011 
One-, two-, and three-dimensional $\mathrm{M}(\mathrm{II})-\mathrm{H}_{3} \mathrm{HPA}$ hybrids possessing a rich variety of architectures and topologies with variable coordination modes have been reported. ${ }^{14}$ Some of these materials could be synthesized as single crystals, ${ }^{11}$ demonstrating their potential for crystal engineering. From previous studies, it was apparent that solids with low dimensionality tend to crystallize at room temperature and low $\mathrm{pH}$, whereas hydrothermal reactions result in $2 \mathrm{D}$ or $3 \mathrm{D}$ frameworks, the latter usually incorporating various alkaline cations for charge compensation. ${ }^{14}$ The systematic investigation of $\mathrm{pH}$ and temperature using high-throughput methods have been previously reported for other metal phosphonates showing similar trends. ${ }^{15}$ The 3D anionic networks are obtained by buffering the $\mathrm{pH}$ of the initial solution with acetate salts (i.e., higher $\mathrm{pH}$ ) and increasing the ratio $\mathrm{M}^{2+} / \mathrm{H}_{3} \mathrm{HPA}$ or the $\mathrm{A}^{+} / \mathrm{M}^{2+}$ ratio $(\mathrm{A}=\mathrm{Na}, \mathrm{K})$. For these solids, increasing dimensionality can be envisaged as a result of cross-linking between the polymeric units formed at low temperature, through subtle coordination changes at the metal centers. A common structural feature for $\mathrm{M}(\mathrm{II})-\mathrm{H}_{3} \mathrm{HPA}$ hybrids is the predominance of the octahedral coordination for the divalent metal ion, despite the preparation procedures and ion size disparities. Among all divalent transition metal ions studied, only $\mathrm{Zn}^{2+}$ has been reported to show a tetrahedral coordination under quite specific experimental conditions. ${ }^{16}$ On the other hand, the larger alkaline earth ions have been found to be eight-coordinated $\left(\mathrm{Sr}^{2+}\right)$, forming 2D layered polymers, or nine-coordinated in 3D structures $\left(\mathrm{Sr}^{2+}, \mathrm{Ba}^{2+}\right) \cdot{ }^{17} \mathrm{Ca}^{2+}$ is quite unique as evidenced by a reported hybrid that displays simultaneously a central $\mathrm{CaO}_{6}$ group connected to two $\mathrm{CaO}_{8}$ side units forming a linear trimer. ${ }^{11 \mathrm{la}}$ This compound, $\mathrm{Ca}_{3}(\mathrm{HPA})_{2}\left(\mathrm{H}_{2} \mathrm{O}\right)_{14}$, has been reported to be an effective corrosion inhibitor for carbon steel surfaces. ${ }^{11 a}$

Given the versatility shown by $\mathrm{Ca}^{2+}$ upon $\mathrm{H}_{3} \mathrm{HPA}$ coordination, we have undertaken a systematic study of the $\mathrm{Ca}^{2+}-\mathrm{H}_{3} \mathrm{HPA}$ system, in order to determine the structural variations and define the synthesis parameters for the crystalline phases formed at RT and hydrothermally, at $180^{\circ} \mathrm{C}$. For the latter procedure, a parallel synthesis methodology was applied. Four new structures have been derived from single-crystal and powder diffraction data and thoroughly analyzed. Furthermore, the compounds have been characterized by a number of techniques including infrared spectroscopy and thermal analysis. A key finding of this study is the repeated occurrence of a common calcium-based trimeric inorganic moiety. Its recognition is the basis for understanding important structural features and perhaps for predicting product structures in future preparations of this large family of compounds.

\section{EXPERIMENTAL SECTION}

General Procedures. A racemic mixture of $\mathrm{R}, \mathrm{S}-\mathrm{H}_{3} \mathrm{HPA}(50 \% \mathrm{w} / \mathrm{w}$ stock solution in water, under the commercial name Belcor 575) was purchased from IMC, Spain, or from Biolabs, UK. Stock solutions of $\mathrm{HCl}$ and $\mathrm{AOH}\left(\mathrm{A}=\mathrm{Li}^{+}, \mathrm{Na}^{+}, \mathrm{K}^{+}\right)$were used for $\mathrm{pH}$ adjustments; for concentrations see below. Hydrothermal reactions were carried out using a parallel synthesis procedure in an autoclave block made of aluminum, which contains 36 reaction chambers in a $6 \times 6$ array. Teflon reactors have an inner diameter of $19 \mathrm{~mm}$ and a depth of $18 \mathrm{~mm}$, with a total volume of about $5 \mathrm{~mL}$. A thin sheet of Teflon covers the reaction vessels, which are then sealed inside a specially designed aluminum autoclave. A photograph of the system is given in the Supporting Information. In-house, deionized water was used for all syntheses. Selected synthesis parameters including starting and final $\mathrm{pH}$ values are given in Table S1, see Supporting Information. Water-soluble metal salts were commercial samples and were used without further purification. Elemental analyses $(\mathrm{C}, \mathrm{H}, \mathrm{N})$ were measured on a Perkin-Elmer 240 analyzer. Thermogravimetric analysis (TGA) data were recorded on an SDT-Q600 analyzer from TA Instruments. The temperature varied from RT to $900{ }^{\circ} \mathrm{C}$ at a heating rate of $10^{\circ} \mathrm{C} \cdot \mathrm{min}^{-1}$. Measurements were carried out on samples in open platinum crucibles under air flow. Infrared spectra were obtained with an ATR accessory (MIRacle ATR, PIKE Technologies, USA) coupled to an FTIR spectrometer (FT/IR4100, JASCO, Spain). All spectra were recorded in the 4000 to $600 \mathrm{~cm}^{-1}$ range at $4 \mathrm{~cm}^{-1}$ resolution, and 50 scans were accumulated.

Materials Syntheses. Room Temperature Synthesis

$\mathrm{Ca}_{3}\left(\mathrm{O}_{3} \mathrm{PCHOHCOO}\right)_{2} \cdot 14 \mathrm{H}_{2} \mathrm{O}$ (1). Compound 1 was prepared following the procedure previously described at $\mathrm{pH}=7.3 .{ }^{11 \mathrm{a}} \mathrm{IR}$ data $/ \mathrm{cm}^{-1}: 3569$ (sh), 3327 (sh), 3232 (br), 2946 (w), 1639 (w), $1582(\mathrm{~m}), 1427(\mathrm{~m})$, $1367(\mathrm{w}), 1264(\mathrm{~m}), 1202(\mathrm{~m}), 1086(\mathrm{sh}), 1059(\mathrm{~s}), 979(\mathrm{~s}), 832(\mathrm{w})$.

$\mathrm{Ca}\left(\mathrm{HO}_{3} \mathrm{PCHOHCOO}\right) \cdot 3 \mathrm{H}_{2} \mathrm{O}$ (2). A quantity of $\mathrm{H}_{3} \mathrm{HPA}(0.5 \mathrm{~mL}$ of a $50 \% \mathrm{w} / \mathrm{w}$ aqueous solution, $2.195 \mathrm{mmol}$ ) was dissolved in deionized water $(25 \mathrm{~mL})$, and hydrated calcium chloride $(2.195 \mathrm{mmol})$ was added stepwise under vigorous stirring. Solution $\mathrm{pH}$ was adjusted to 2.0 and 4.06 with 1.0 or $5.0 \mathrm{M} \mathrm{NaOH}$ solutions, respectively. For the $\mathrm{pH}=2$ preparation, the clear slightly yellow solution was stored at ambient temperature. The reaction solution yielded a crystalline material after 3 days $(\sim 50 \%$ based on metal). If crystallization is left to proceed over 1 week, higher yield is obtained ( $\sim 60 \%$ based on metal). The precipitate was isolated by filtration and air-dried. Anal. Calcd (\%) for $\mathrm{CaC}_{2} \mathrm{H}_{9} \mathrm{O}_{9} \mathrm{P}: 9.68 \% \mathrm{C}, 3.66 \% \mathrm{H}$. Found: 9.78\%C, 3.15\%H. IR data/cm ${ }^{-1}$ : 3534 (br), 3393 (br), 3193 (br), 2945 (w), $2872(\mathrm{w}), 2815(\mathrm{w}), 2765(\mathrm{w}) 2716(\mathrm{w}), 2669(\mathrm{w}), 1638(\mathrm{sh}), 1587$ (s), $1441(\mathrm{~m}), 1389(\mathrm{~m}), 1288(\mathrm{~m}), 1186(\mathrm{~m}), 1160(\mathrm{~s}), 1076$ (m), 1051 (s), $967(\mathrm{w}), 927(\mathrm{~s}), 821(\mathrm{w})$. For the $\mathrm{pH}=4.06$ preparation, an unknown, unidentified as of yet, phase was obtained.

Hydrothermal Synthesis. $\mathrm{Ca}\left(\mathrm{NO}_{3}\right)_{2} \cdot 3 \mathrm{H}_{2} \mathrm{O}(2.23 \mathrm{mmol})$ was added to a solution formed by $0.5 \mathrm{~mL}$ of the ligand stock solution $(2.23 \mathrm{mmol})$ and deionized water $(1.5 \mathrm{~mL})$ under stirring. A fixed molar ratio, $\mathrm{Ca}^{2+}$ / $\mathrm{H}_{3} \mathrm{HPA}=1: 1$, was used. Solution $\mathrm{pH}$ was adjusted to the desired value, between 1.0 and 7.2, with solid $\mathrm{AOH}\left(\mathrm{A}=\mathrm{Li}^{+}, \mathrm{Na}^{+}, \mathrm{K}^{+}\right)$or the corresponding 5.0 M stock solutions. The reactions were maintained for 3 days at $180^{\circ} \mathrm{C}$ in a Teflon-lined autoclave. The resulting solids were filtered off, washed twice with deionized water, and dried at $50{ }^{\circ} \mathrm{C}$.

$\mathrm{Ca}_{5}\left(\mathrm{O}_{3} \mathrm{PCHOHCOO}\right)_{2}\left(\mathrm{HO}_{3} \mathrm{PCHOHCOO}\right)_{2} \cdot 6 \mathrm{H}_{2} \mathrm{O}$ (3). Compound 3 was prepared using $\mathrm{CaO}$ as the source of $\mathrm{Ca}^{2+}$ and using a $\mathrm{Ca}^{2+} /$ $\mathrm{H}_{3} \mathrm{HPA}$ molar ratio between $1: 1$ and 2.17:1 ( $\mathrm{pH}$ initial values ranged between 0.61 and 4.6 ) with a yield close to $25 \%$ (based on calcium). Anal. Calcd (\%) for $\mathrm{Ca}_{5} \mathrm{C}_{8} \mathrm{H}_{22} \mathrm{O}_{30} \mathrm{P}_{4}: 10.42 \% \mathrm{C}, 2.40 \% \mathrm{H}$. Found: $10.38 \% \mathrm{C}, 2.12 \% \mathrm{H}$. Compound 3 was also obtained as above but using $\mathrm{Ca}\left(\mathrm{NO}_{3}\right)_{2} \cdot 3 \mathrm{H}_{2} \mathrm{O}$ and $\mathrm{KOH}$ to increase the $\mathrm{pH}$, with a yield of $73 \%$. Compound 3 was also isolated at $\mathrm{pH}$ lower than 1.5 when $\mathrm{NaOH}$ is added to regulate the $\mathrm{pH}$, yield $83 \%$. IR data $/ \mathrm{cm}^{-1}: 3507$ (sh), 3228 (br), 3084 (sh), $2806(\mathrm{w}), 2724(\mathrm{w}), 1615(\mathrm{~m}), 1586(\mathrm{~s}), 1454(\mathrm{w}), 1423(\mathrm{~m}), 1405$ (m) $1289(\mathrm{w}), 1249(\mathrm{w}), 1210(\mathrm{w}), 1160(\mathrm{~m}), 1136(\mathrm{~m}), 1089(\mathrm{w}), 1061$ (s), $994(\mathrm{~m}), 968(\mathrm{sh}), 943(\mathrm{~m}), 915(\mathrm{~m}), 837(\mathrm{~m})$.

$\mathrm{CaLi}\left(\mathrm{O}_{3} \mathrm{PCHOHCOO}\right)$ (4) and $\mathrm{Ca}_{2} \mathrm{Na}\left(\mathrm{O}_{3} \mathrm{PCHOHCOO}\right)\left(\mathrm{HO}_{3} \mathrm{PCH}\right.$ $\mathrm{OHCOO}) \cdot 1.5 \mathrm{H}_{2} \mathrm{O}$ (5). Single phases $\mathrm{CaLi}\left(\mathrm{O}_{3} \mathrm{PCHOHCOO}\right)(4)$ and $\mathrm{Ca}_{2} \mathrm{Na}\left(\mathrm{O}_{3} \mathrm{PCHOHCOO}\right)\left(\mathrm{HO}_{3} \mathrm{PCHOHCOO}\right) \cdot 1.5 \mathrm{H}_{2} \mathrm{O}$ (5) were obtained within a wide $\mathrm{pH}$ range, between 1.0 and 4.3 for $\mathbf{4}$ and from 1.0 to 7.2 for $\mathbf{5}$, following the general description described above. Anal. Calcd (\%) for $\mathrm{CaLiC}_{2} \mathrm{H}_{2} \mathrm{O}_{6} \mathrm{P}: 12.01 \% \mathrm{C}, 1.01 \% \mathrm{H}$. Found: $10.55 \% \mathrm{C}, 1.13 \% \mathrm{H}$. Yield: $81 \%$ (based on metal). IR data $/ \mathrm{cm}^{-1}$ : 3083 (br), 2972 (w), 2677 (w), 2613 (sh), $1620(\mathrm{w}), 1575$ (s), 1432 (s), $1364(\mathrm{sh}), 1350$ (m), 1273 (m), 1165 (m), $1146(\mathrm{~m}), 1128(\mathrm{~m}), 1077$ (s), 1045 (m), $979(\mathrm{~s}), 953$ (w), 837 (m). Anal. Calcd (\%) for $\mathrm{Ca}_{2} \mathrm{NaC}_{4} \mathrm{H}_{8} \mathrm{O}_{13.5} \mathrm{P}_{2}: 10.99 \% \mathrm{C}, 1.84 \% \mathrm{H}$. Found: $9.83 \%$ C, $1.64 \%$ H. Yield: $65 \%$ (based on metal). IR data $/ \mathrm{cm}^{-1}: 3530$ (sh), 3206 (br), 2913 (sh), 2843 (w), 2758 (w), 2643 (w), 1588 (m), 1446 (sh), 1412 (m), $1358(\mathrm{w}), 1306(\mathrm{w}), 1256(\mathrm{w}), 1185$ (sh), 1160 (sh), 1130 (sh), 1120 (m), 1060 (s), 985 (m), 960 (sh), $916(\mathrm{w}), 858(\mathrm{w}), 834(\mathrm{w})$. 
Structural Determinations. Laboratory X-ray powder diffraction (XRPD) patterns were collected on a PANanalytical X'Pert Pro diffractometer. XRPD patterns corresponding to the single phases were autoindexed using the DICVOL06 program, ${ }^{18}$ and the space groups were derived from the observed systematic extinctions. To minimize the preferred orientation effects, XRPD patterns of $\mathbf{2}$ and $\mathbf{4}$ for $a b$ initio structure determination (samples within rotating borosilicate glass capillaries of diameter of $0.5 \mathrm{~mm}$ ) were recorded in Debye-Scherrer transmission configuration by using a hybrid $\mathrm{Ge}(220)$ primary monochromator $\left(\mathrm{Cu} \mathrm{K \alpha}{ }_{1}\right.$ radiation) and the X'Celerator detector. For 2, the XRPD pattern was recorded between $9^{\circ}$ and $80^{\circ}(2 \theta), 0.017^{\circ}$ step size, and an equivalent counting time of ca. $1300 \mathrm{~s} / \mathrm{step}$. For 4 , the scanned angular region was $5-100^{\circ}$ in $2 \theta$ with a step size of $0.017^{\circ}(2 \theta)$ and an equivalent counting time of ca. $1000 \mathrm{~s} /$ step. Additionally and in order to carry out the final Rietveld refinement for $\mathbf{2}$, a second pattern was recorded in a Bragg-Brentano reflection configuration by using a $\mathrm{Ge}(111)$ primary monochromator $\left(\mathrm{Cu} \mathrm{K} \alpha_{1}\right)$ and the $\mathrm{X}$ 'Celerator detector. This X-ray pattern was collected between $5^{\circ}$ and $100^{\circ}$ in $2 \theta$ with the same step size and an equivalent counting time of $356 \mathrm{~s} / \mathrm{step}$. This second pattern was collected because the reflection geometry allows measurable diffraction peaks at higher diffraction angles although the pattern displays a larger preferred orientation effect. The crystal structures of $\mathbf{2}$ and $\mathbf{4}$ were solved following an ab initio methodology using the transmission patterns. Structure determination was carried out by direct methods using the program EXPO2009. ${ }^{19}$ A partial structural model was obtained for $\mathbf{2}$, while for $\mathbf{4}$ the full content of the asymmetric unit was given by the default setting of the program. The final structure for $\mathbf{2}$ was derived from the analysis of the pattern collected in reflection geometry.

For 3, a high-resolution synchrotron powder data set was collected on the ID31 powder diffractometer of ESRF, European Synchrotron Radiation Facility, (Grenoble, France) using a short wavelength $\lambda=$ $0.2998 \AA$ A selected with a double-crystal $\mathrm{Si}(111)$ monochromator and calibrated with Si NIST $(a=5.43094 \AA)$. The Debye-Scherrer configuration was used with the sample loaded in a rotating borosilicate glass capillary of diameter of $1.0 \mathrm{~mm}$. The overall measuring time was $\sim 100 \mathrm{~min}$ to have very good statistics over the angular range $1.5-20^{\circ}$ (in $2 \theta$ ). The data from the multianalyzer $\operatorname{Si}(111)$ stage were normalized and summed into $0.003^{\circ}$ step size with local software. The crystal structure of $\mathbf{3}$ was also solved following an $a b$ initio methodology. The integrated intensities extracted with the program Ajust ${ }^{20}$ were introduced in the direct methods program XLENS. ${ }^{21}$ The number of large and weak $E$ values actively used were 290 and 874, respectively. The starting framework model was derived from the interpretation of the electron density map computed with the set of refined phases with the highest combined figure of merit.

In general, the missing atoms were localized by difference of Fourier maps. All crystal structures were refined by the Rietveld method ${ }^{22}$ by using the GSAS package ${ }^{23}$ with soft constraints to maintain chemically reasonable geometries for the phosphonate, chain, and carboxylic groups. The soft constraints were as follows: $\mathrm{PO}_{3} \mathrm{C}_{1}$ tetrahedron, $\mathrm{P}-\mathrm{O}[1.53(1) \AA], \mathrm{P}-\mathrm{C}_{1}[1.80(1) \AA], \mathrm{O} \cdots \mathrm{O}[2.55(2) \AA], \mathrm{O} \cdots \mathrm{C}_{1}$ $[2.73(2) \AA] ; \mathrm{C}_{1} \mathrm{OH}-\mathrm{C}_{2} \mathrm{OO}$ group, $\mathrm{C}_{1}-\mathrm{C}_{2}[1.50(1) \AA], \mathrm{C}_{2}-\mathrm{O}_{\text {carb }}$ [1.23(1) $\AA], \mathrm{C}_{1}-\mathrm{OH}[1.40(1) \AA], \mathrm{P} \cdots \mathrm{OH}[2.68(2) \AA], \mathrm{C}_{2}-\mathrm{OH}$ $[2.40(2) \AA], \mathrm{O}_{\text {carb }} \cdots \mathrm{O}_{\text {carb }}[2.21(2) \AA], \mathrm{C}_{1} \cdots \mathrm{O}_{\text {carb }}[2.36(2) \AA]$. No attempts to locate the $\mathrm{H}$ atoms were carried out due to the limited quality of the XRPD data. All atoms were isotropically refined using specific restrains. Crystallographic data are presented in Table 1 and the final Rietveld plots for phases 2, 3, and $\mathbf{4}$ are given in the Supporting Information. Crystal structures have been deposited at the CCDC, and the reference codes are also given in Table 1.

Suitable single crystals of $\mathbf{5}$ were obtained, so a crystal was mounted on a glass fiber and used for data collection. Data were recorded in a Bruker SMART APEX diffractometer at $298 \mathrm{~K}$ using Mo radiation. The data were processed with APEX2 ${ }^{24}$ and corrected for absorption using SADABS. ${ }^{25}$ The structure was solved by direct methods, ${ }^{26}$ revealing the positions of all non-hydrogen atoms. These atoms were refined on $F^{2}$ by full-matrix least-squares procedure ${ }^{27}$ using anisotropic displacement parameters except the sodium atom and the oxygens corresponding to the water molecules, which were refined isotropically. All hydrogens, except those of water molecules, were located in difference Fourier maps and included as fixed contributions riding on attached atoms with isotropic thermal displacement parameters 1.2 times those of the respective atom. Crystallographic and structure refinement data are also given in Table 1.

Good quality single crystals of $\mathbf{1}$ were grown from the synthesis medium. Data were collected on a Nonius Kappa CCD area detector diffractometer at $150(2) \mathrm{K}$ with $\mathrm{Mo} \mathrm{K} \alpha(\lambda=0.71073 \AA)$. The structure was solved by direct methods, ${ }^{26}$ revealing the positions of all nonhydrogen atoms. These atoms were refined on $F^{2}$ by full-matrix leastsquares procedure ${ }^{27}$ using anisotropic displacement parameters. Crystallographic and structure refinement data are also given in Table 1.

A thermodiffractometric study for $\mathbf{3}$ was carried out for the sample loaded in an Anton Paar TTK450 camera under static air. Flow of gases was not employed in order to avoid sample dehydration prior to the diffraction experiment. Data were collected at different temperature intervals from room temperature to $260{ }^{\circ} \mathrm{C}$ with a heating rate of $5^{\circ} \mathrm{C} \cdot \mathrm{min}^{-1}$ and a delay time of $5 \mathrm{~min}$ to ensure thermal stabilization. The data acquisition range was $4-70^{\circ}(2 \theta)$ with a step size of $0.017^{\circ}$.

\section{RESULTS AND DISCUSSION}

Calcium hydroxyphosphonoacetate hybrid materials show a rich variety of structural architectures, depending on the synthesis conditions. Four variables have been analyzed in this work: $\mathrm{Ca}^{2+} / \mathrm{H}_{3} \mathrm{HPA}$ molar ratio, temperature, initial $\mathrm{pH}$, and the presence of alkali ions. Table 2 summarizes the chemical composition of the isolated phases and the experimental conditions yielding the highest crystalline solids. The crystallization diagram as a function of the initial $\mathrm{pH}$ is shown in Figure 1. Two single-phase compounds were isolated at room temperature, 1 and 2, at slightly basic and low $\mathrm{pH}$, respectively. An unknown compound(s), prepared by adjusting the initial $\mathrm{pH}$ at 4.06 with $\mathrm{NaOH}$ or $\mathrm{KOH}$ solutions, was obtained, but it could not be indexed. However, this compound, upon hydrothermal treatment at $180^{\circ} \mathrm{C}$ in aqueous suspension, evolves to 3 . As it can be seen in Figure 1, this phase exhibits the broadest $\mathrm{pH}$ stability range, among all prepared compounds. Compound 3 could be synthesized in a wide range of $\mathrm{Ca}^{2+} / \mathrm{H}_{3} \mathrm{HPA}$ molar ratios and $\mathrm{Na}^{+}$or $\mathrm{K}^{+}$concentrations. These findings points to 3 as having the largest stability field within the explored experimental conditions. Nevertheless, addition of $\mathrm{LiOH}$ to the initial reaction mixture led to 4. This phase is fully deprotonated and is stable, even at $\mathrm{pH}=1$, which reveals that $\mathrm{Li}^{+}$plays a remarkable structural role in this framework. Conversely, quite large alkaline ions, such as $\mathrm{K}^{+}$, are not incorporated within the structure of $\mathrm{Ca}-\mathrm{H}_{3} \mathrm{HPA}$ hybrids. $\mathrm{Na}^{+}$seems to play an intermediate role, acting as a charge-compensating cation in a new phase, $\mathbf{5}$, formed at initial $\mathrm{pH}$ higher than 2 .

Thermogravimetric analyses for compounds 1, 2, 3, 4, and 5 are displayed in Figure 2. Data for $\mathbf{2}$ are shown here for comparison, but they are not discussed because they were previously reported. ${ }^{17}$ The first step in the mass loss curve for $\mathbf{1}$ occurs at $150{ }^{\circ} \mathrm{C}$, with an associated weight loss of $33.5 \%$, closely corresponding to the loss of 11 water molecules (33.09\%). The remaining water molecules are progressively lost up to $320^{\circ} \mathrm{C}$, above which, the thermal decomposition of 1 takes place.

The TGA curve of $\mathbf{3}$ exhibits two consecutive mass losses up to $240{ }^{\circ} \mathrm{C}$ followed by a plateau up to $300^{\circ} \mathrm{C}$. The observed weight loss, $7.1 \%$, is in relatively good agreement with that calculated for 
Table 1. Crystallographic Data for Calcium Hydroxyphosphonoacetate Hybrid Materials

\begin{tabular}{|c|c|c|c|c|c|}
\hline $\begin{array}{l}\text { phase } \\
\text { empirical formula }\end{array}$ & ${ }_{\mathrm{Ca}_{3} \mathrm{C}_{4} \mathrm{H}_{32} \mathrm{P}_{2} \mathrm{O}_{26}}$ & $\begin{array}{l}2 \\
\mathrm{CaC}_{2} \mathrm{H}_{9} \mathrm{O}_{9} \mathrm{P}\end{array}$ & $\begin{array}{l}3 \\
\mathrm{Ca}_{5} \mathrm{C}_{8} \mathrm{H}_{22} \mathrm{O}_{30} \mathrm{P}_{4}\end{array}$ & $\begin{array}{l}4 \\
\mathrm{CaLiC}\end{array} \mathrm{H}_{2} \mathrm{O}_{6} \mathrm{P}$ & $\begin{array}{l}5 \\
\mathrm{Ca}_{2} \mathrm{NaC}_{4} \mathrm{H}_{8} \mathrm{O}_{13.5} \mathrm{P}_{2}\end{array}$ \\
\hline $\mathrm{FW}\left(\mathrm{g} \cdot \mathrm{mol}^{-1}\right)$ & 678.48 & 248.14 & 922.53 & 200.03 & 437.19 \\
\hline space group & $P \overline{1}$ & $P 2_{1} n b$ & $I 12 / a 1$ & $P 12_{1} / a 1$ & $P \overline{1}$ \\
\hline$\lambda(\AA)$ & 0.71073 & 1.5406 & 0.29998 & 1.5406 & 0.71073 \\
\hline$a(\AA)$ & $6.29940(10)$ & $12.04034(28)$ & $29.7116(4)$ & $10.12041(21)$ & $6.6400(7)$ \\
\hline$b(\AA)$ & $9.2525(2)$ & $23.2258(5)$ & $8.84842(9)$ & $8.59419(17)$ & $8.7164(9)$ \\
\hline$c(\AA)$ & $11.2079(2)$ & $5.81578(13)$ & $11.31039(9)$ & $6.07635(13)$ & $11.5047(12)$ \\
\hline$\alpha(\operatorname{deg})$ & $66.7085(11)$ & 90.0 & 90.0 & 90.0 & $76.174(1)$ \\
\hline$\beta(\operatorname{deg})$ & $86.1892(11)$ & 90.0 & $93.2400(8)$ & $92.438(1)$ & $89.574(1)$ \\
\hline$\gamma(\operatorname{deg})$ & $87.2087(10)$ & 90.0 & 90.0 & 90.0 & $75.524(1)$ \\
\hline$V\left(\AA^{3}\right)$ & $598.512(19)$ & $1626.36(8)$ & $2968.52(6)$ & $528.02(2)$ & $625.07(11)$ \\
\hline crystal size $\left(\mathrm{mm}^{3}\right)$ & $0.35 \times 0.25 \times 0.2$ & & & & $0.08 \times 0.06 \times 0.02$ \\
\hline Z & 1 & 8 & 4 & 4 & 1 \\
\hline $\mathrm{V}\left(\AA^{3} \text { atom }^{-1}\right)^{a}$ & 17.1 & 15.6 & 16.5 & 12.0 & 13.9 \\
\hline$\rho_{\text {calc }}\left(\mathrm{g} \cdot \mathrm{cm}^{-3}\right)$ & 1.882 & 1.952 & 2.014 & 2.492 & 2.307 \\
\hline $2 \theta$ range $(\mathrm{deg})$ & $2.00-27.50$ & $4.98-100$ & $1.50-20.00$ & $4.01-99.99$ & $1.83-25.00$ \\
\hline data/restraints/params & $2730 / 0 / 220$ & $2746 / 38 / 129$ & $6211 / 45 / 133$ & $5669 / 23 / 58$ & $2172 / 0 / 198$ \\
\hline no. reflns & 2730 & 776 & 2423 & 539 & 2172 \\
\hline indep. reflns $[I>2 \sigma(I)]$ & 2528 & & & & 2050 \\
\hline$R_{\mathrm{wp}}$ & & 0.097 & 0.1147 & 0.0659 & \\
\hline$R_{\mathrm{p}}$ & & 0.0737 & 0.0838 & 0.0504 & \\
\hline$R_{\mathrm{F}}$ & & 0.0877 & 0.0693 & 0.0524 & \\
\hline GOF, $F^{2}$ & 1.053 & & & & 1.194 \\
\hline$R$ factor $[I>2 \sigma(I)]$ & $\mathrm{R} 1=0.0212^{b}$ & & & & $\mathrm{R} 1=0.0560^{b}$ \\
\hline \multirow{3}{*}{$R$ factor (all data) } & $\mathrm{wR} 2=0.0572^{b}$ & & & & $\mathrm{wR} 2=0.1532^{b}$ \\
\hline & $\mathrm{R} 1=0.0234^{b}$ & & & & $\mathrm{R} 1=0.0585^{b}$ \\
\hline & $\mathrm{wR} 2=0.0584^{b}$ & & & & $\mathrm{wR} 2=0.1545^{b}$ \\
\hline CCDC reference code & 766599 & 801008 & 801011 & 801009 & 801010 \\
\hline
\end{tabular}

Table 2. Stoichiometry, Experimental Conditions and Dimensionality for the Isolated Phases

\begin{tabular}{|c|c|c|c|c|}
\hline phase & $\mathrm{pH}$ & $T\left({ }^{\circ} \mathrm{C}\right)$ & added cation & chemical formula/dimensionality \\
\hline 1 & 7.3 & RT & $\mathrm{Na}^{+}$ & $\mathrm{Ca}_{3}\left(\mathrm{O}_{3} \mathrm{PCHOHCOO}\right)_{2} \cdot 14 \mathrm{H}_{2} \mathrm{O} / 0 \mathrm{D}$ \\
\hline 2 & 2.0 & RT & $\mathrm{Na}^{+}$ & $\mathrm{Ca}\left(\mathrm{HO}_{3} \mathrm{PCHOHCOO}\right) \cdot 3 \mathrm{H}_{2} \mathrm{O} / 2 \mathrm{D}$ \\
\hline 3 & 4.3 & 180 & $\mathrm{~K}^{+}$ & $\mathrm{Ca}_{5}\left(\mathrm{O}_{3} \mathrm{PCHOHCOO}\right)_{2}\left(\mathrm{HO}_{3} \mathrm{PCHOHCOO}\right)_{2} \cdot 6 \mathrm{H}_{2} \mathrm{O} / 3 \mathrm{D}$ \\
\hline 4 & 4.3 & 180 & $\mathrm{Li}^{+}$ & $\mathrm{CaLi}\left(\mathrm{O}_{3} \mathrm{PCHOHCOO}\right) / 3 \mathrm{D}$ \\
\hline 5 & 4.3 & 180 & $\mathrm{Na}^{+}$ & $\mathrm{Ca}_{2} \mathrm{Na}\left(\mathrm{O}_{3} \mathrm{PCHOHCOO}\right)\left(\mathrm{HO}_{3} \mathrm{PCHOHCOO}\right) \cdot 1.5 \mathrm{H}_{2} \mathrm{O} / 2 \mathrm{D}$ \\
\hline
\end{tabular}

the loss of four hydration water molecules, $7.8 \%$. The remaining two water molecules are lost above $300{ }^{\circ} \mathrm{C}$, a process that overlaps with thermal combustion of the organic moieties. On the other hand, 4 is stable until $380{ }^{\circ} \mathrm{C}$ showing a single-step weight loss, attributed to the combustion of the organic moieties. The thermal behavior of $\mathbf{5}$ is characterized by a gradual weight loss before the combustion of the organic moieties. There are two small mass losses between 90 and $220{ }^{\circ} \mathrm{C}$, with an overall associated weigh loss of $2.37 \%$, closely corresponding to the loss of a half water molecule, $2.06 \%$. A third weight loss between 200 and $750{ }^{\circ} \mathrm{C}$ is attributed to overlapped processes of dehydration and combustion.

Thermodiffraction patterns were recorded for 3, see Supporting Information, in order to study its thermal evolution. Only small changes in the position and intensities of the diffraction peaks are observed up to $260^{\circ} \mathrm{C}$, which confirms the robustness of the framework prior to its thermal decomposition. However, it was not possible to index the XRPD pattern of this phase at intermediate temperatures. No reversible hydration of this phase was detected on cooling.

Representative IR spectra for the prepared phases, between 4000 and $1400 \mathrm{~cm}^{-1}$, are given in Figure 3. This spectral region was selected in order to get complementary information about the band shifts of the carboxylate and $\mathrm{PO}-\mathrm{H}$ groups, together with those characteristics of the water molecules. Conversely to other metal carboxyphosphonates, ${ }^{8 c}$ the protonated carboxylate group was absent in all of these calcium hydroxyphosphonoacetates. This common structural characteristic was obtained in the crystal structure studies, see below, and corroborated in the IR study as deduced from the systematic absence of the IR signal at $1715 \mathrm{~cm}^{-1}$ corresponding to the asymmetric $v(\mathrm{C}=\mathrm{O})$ stretch of the free acid $(-\mathrm{COOH})$. Instead of this band, intense bands 


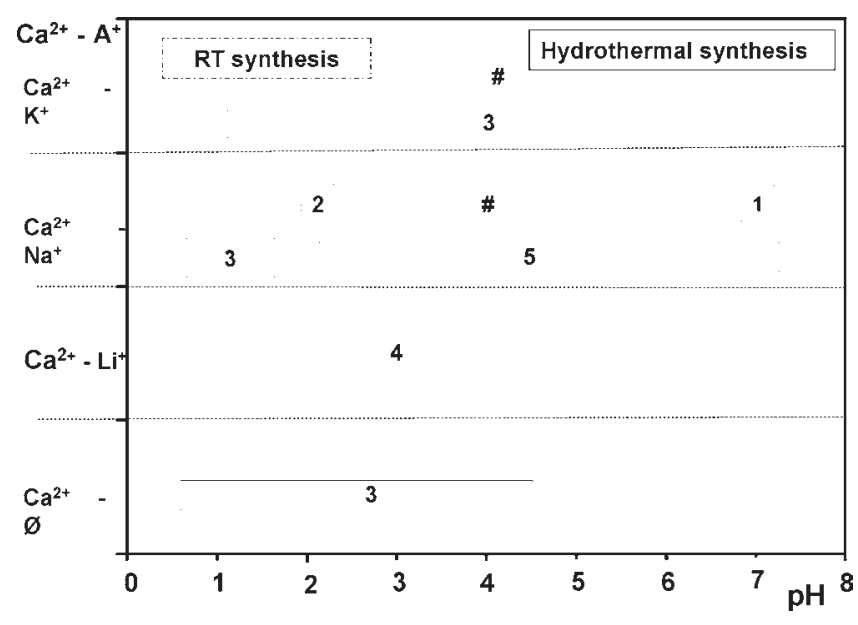

Figure 1. Stability range for $\mathrm{Ca}-\mathrm{H}_{3} \mathrm{HPA}$ derivatives as a function of the initial $\mathrm{pH}$ and the addition of alkaline cations. For alkaline-containing preparations, the $\mathrm{Ca} / \mathrm{H}_{3} \mathrm{HPA}$ molar ratio was kept fixed to 1.0 ; \# indicates unknown phase(s).

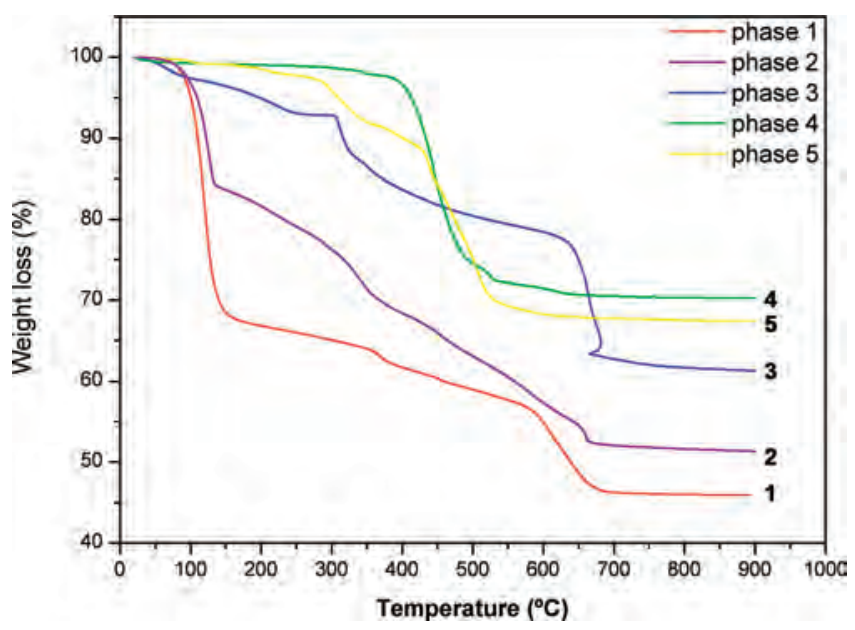

Figure 2. TGA curves for the studied phases: $\mathrm{Ca}_{3}\left(\mathrm{O}_{3} \mathrm{PCHO}\right.$ $\mathrm{HCOO})_{2} \cdot 14 \mathrm{H}_{2} \mathrm{O}$ (1); $\mathrm{Ca}\left(\mathrm{HO}_{3} \mathrm{PCHOHCOO}\right) \cdot 3 \mathrm{H}_{2} \mathrm{O}$ (2); $\mathrm{Ca}_{5^{-}}$ $\left(\mathrm{O}_{3} \mathrm{PCHOHCOO}\right)_{2}\left(\mathrm{HO}_{3} \mathrm{PCHOHCOO}\right)_{2} \cdot 6 \mathrm{H}_{2} \mathrm{O}$ (3); $\mathrm{CaLi}\left(\mathrm{O}_{3} \mathrm{PCH}\right.$ OHCOO (4); $\mathrm{Ca}_{2} \mathrm{Na}\left(\mathrm{O}_{3} \mathrm{PCHOHCOO}\right)\left(\mathrm{HO}_{3} \mathrm{PCHOHCOO}\right) \cdot$ $1.5 \mathrm{H}_{2} \mathrm{O}(5)$.

were observed around $1583-1570 \mathrm{~cm}^{-1}$ and $1440-1411 \mathrm{~cm}^{-1}$, corresponding to the asymmetric and symmetric vibrations of the carboxylate groups $\left[\mathrm{O}-\mathrm{C}-\mathrm{O}^{-}\right]$, respectively. Several broad and small bands in the region of $2900-2650 \mathrm{~cm}^{-1}$, more visible in the spectra of 2 , are assigned to the presence of hydrogen phosphonate, $\mathrm{H}-\mathrm{OPO}_{2} \mathrm{C}$, moieties.

The IR bands in the region $3600-3000 \mathrm{~cm}^{-1}$ are assigned to the $\mathrm{O}-\mathrm{H}$ stretching vibrations of three different moieties: hydroxyl groups of the ligand, hydrogen phosphonate units, and the water molecules. The broadening and splitting of these bands suggests the presence of several types of water molecules interacting through $\mathrm{H}$-bonds with variable intensities, from weak $\left(\sim 3600 \mathrm{~cm}^{-1}\right)$ to strong interaction $\left(\sim 3200 \mathrm{~cm}^{-1}\right)$. It must be noted that only a very low-intensity band centered at $3092 \mathrm{~cm}^{-1}$ was observed for 4. Because this compound does not contain water and hydrogen phosphonate groups, see Table 2, this band

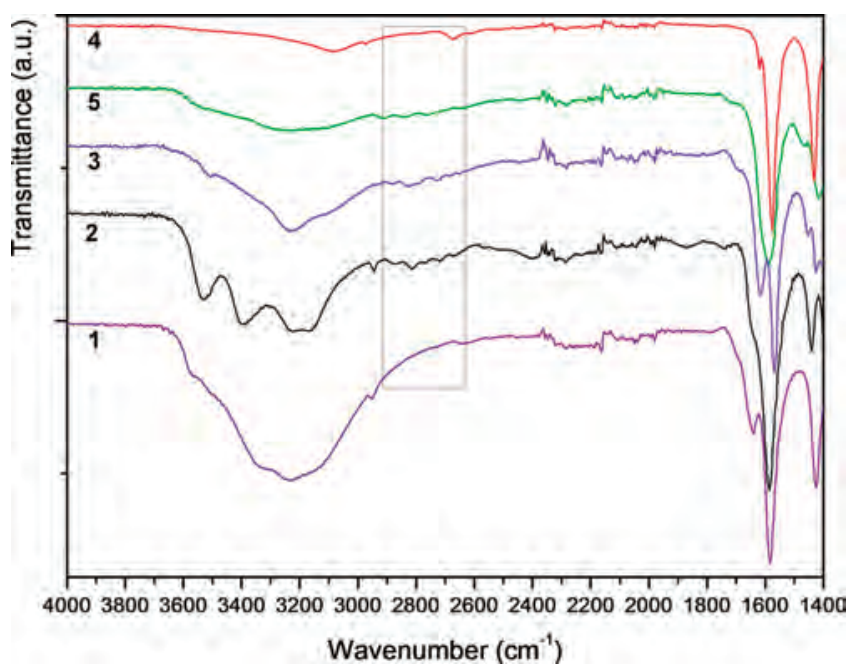

Figure 3. Selected region of the FTIR spectra for compounds $\mathbf{1 - 5}$. The $2900-2650 \mathrm{~cm}^{-1}$ region is highlighted to emphasize the relationship of the bands in that region and the presence of hydrogen phosphonate groups, see Table 2.

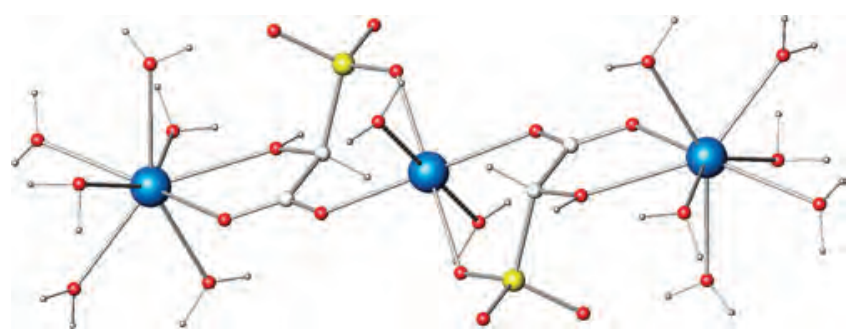

Figure 4. Ball-stick representation of a trimer of $1, \mathrm{Ca}_{3}\left(\mathrm{O}_{3} \mathrm{PCH}\right.$ $(\mathrm{OH}) \mathrm{COO})_{2} \cdot 14 \mathrm{H}_{2} \mathrm{O}$, showing the five- and six-membered rings. $\mathrm{Ca}$, big blue spheres; P, medium-size yellow spheres; C, white balls; $\mathrm{O}$, red balls; $\mathrm{H}$, small gray balls.

must be due to the stretching vibration of the hydroxyl group. Its position is indicative of the existence of a strong metal-oxygen interaction in this solid. All spectra, except that of 4, show the $\delta(\mathrm{H}-\mathrm{O}-\mathrm{H})$ bending vibration of the water molecules at $1640-1615 \mathrm{~cm}^{-1}$, which is partially overlapped with the stretching vibration of the carboxylate groups. Other bands located at lower wavenumbers $\left(<1400 \mathrm{~cm}^{-1}\right)$ corresponding to vibration modes of the $\mathrm{CH}_{2}, \mathrm{PO}_{3} \mathrm{C}, \mathrm{C}-\mathrm{C}$, and $\mathrm{M}-\mathrm{O}$ groups are also present in these IR spectra. ${ }^{8 \mathrm{c}}$

The crystal structure of $1, \mathrm{Ca}_{3}\left(\mathrm{O}_{3} \mathrm{PCHOHCOO}\right)_{2} \cdot 14 \mathrm{H}_{2} \mathrm{O}$, has been recently communicated, and it is described as a molecular linear trimer, ${ }^{11 \mathrm{a}}$ with $\mathrm{Ca}$ atoms being bridged by two fully deprotonated $\mathrm{HPA}^{3-}$ ligands. Both $R$ and $S$ isomers of the ligand are incorporated into the structure, see Figure 4 . The central $\mathrm{Ca}^{2+}$ is found in a distorted octahedral environment, whereas the peripheral $\mathrm{Ca}^{2+}$ centers are in an eight-coordinated environment. The $\mathrm{HPA}^{3-}$ ligands are chelating the central $\mathrm{Ca}^{2+}$ through two pairs of oxygen atoms from the carboxylate and phosphonate groups forming six-membered rings, $\mathrm{Ca}-\mathrm{O}-\mathrm{C}-$ $\mathrm{C}-\mathrm{P}-\mathrm{O}-\mathrm{Ca}$. This coordination mode allows the peripheral $\mathrm{Ca}^{2+}$ ions to bind the ligand through the $\mathrm{OH}$ group and the other carboxylate oxygen, forming a five-membered ring, $\mathrm{Ca}-\mathrm{O}-\mathrm{C}-\mathrm{C}-\mathrm{O}-\mathrm{Ca}$. The remaining coordination sites are occupied by water molecules. 


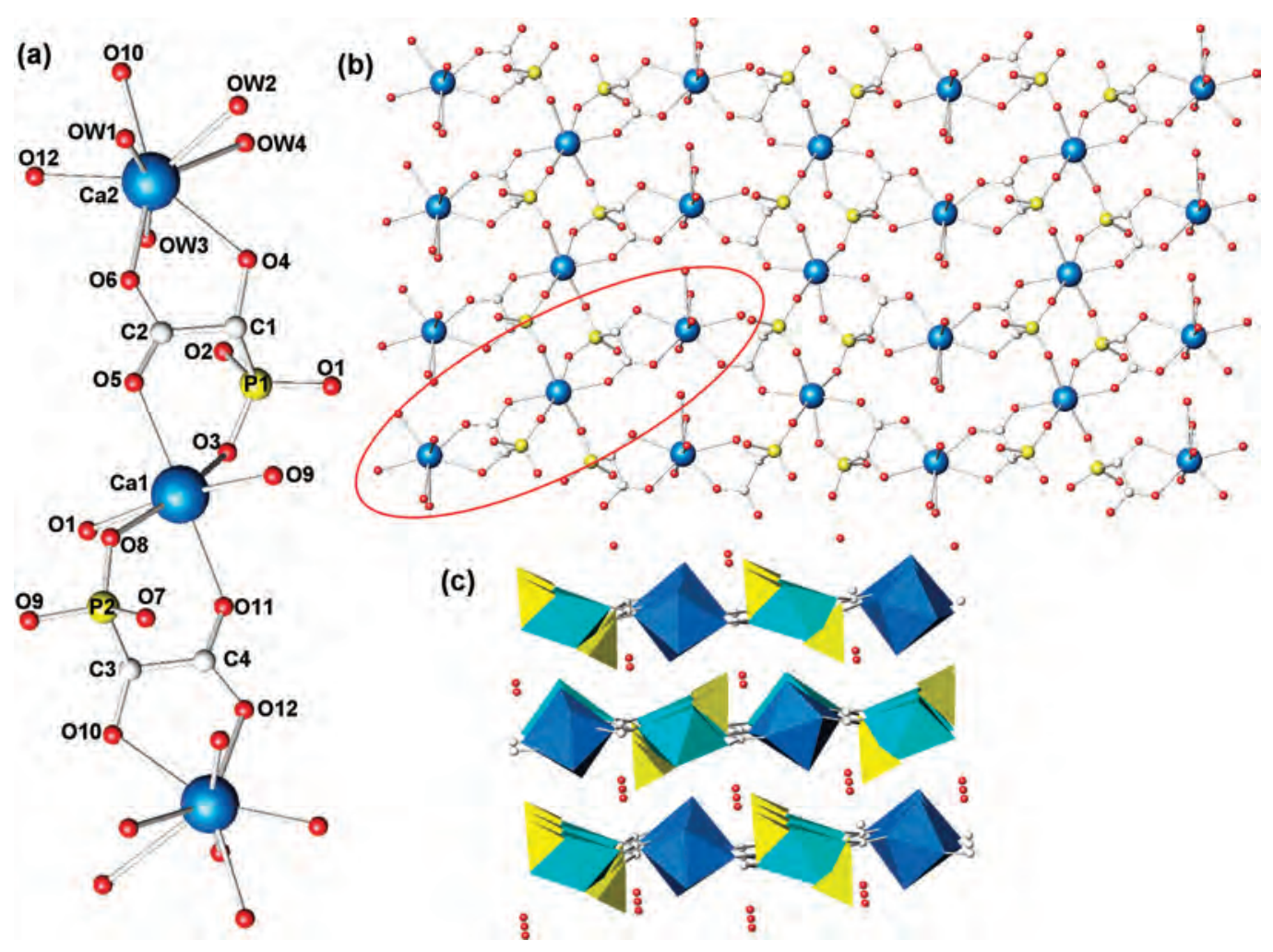

Figure 5. (a) Trimeric unit $\mathrm{CaO}_{8}-\mathrm{CaO}_{6}-\mathrm{CaO}_{8}$ for $\mathrm{Ca}\left(\mathrm{HO}_{3} \mathrm{PCHOHCOO}\right) \cdot 3 \mathrm{H}_{2} \mathrm{O}$ with atoms labeled. (b) View of an organo-inorganic layer, plane bc. (c) Polyhedral view of the layer package along the $[100]$. $\mathrm{CaO}_{6}$, sky-blue octahedra; $\mathrm{CaO}_{8}$, blue polyhedra; $\mathrm{CPO}_{3}$, yellow tetrahedra; $\mathrm{O}$, red balls.

Five- and six-membered chelating rings are frequently found as structural features in metal hydroxyphosphonoacetates. ${ }^{14 a, 17,28}$ However, only a few M(II) derivatives of $\mathrm{H}_{3} \mathrm{HPA}$ (cadmium, ${ }^{29}$ manganese, ${ }^{30}$ and cobalt $^{30}$ ) crystallize with structures containing the same bonding configuration described above: the combination of two central six-membered chelating rings and two external fivemembered chelating rings. Therefore, this structural motif appears to be rather a distinctive feature in the frameworks $\mathrm{M}^{\mathrm{II}}-\mathrm{H}_{3} \mathrm{HPA}$ compounds.

An interesting theme to investigate is whether this single structural unit of $\mathrm{Ca}_{3}(\mathrm{HPA})_{2}$ might be a building block present in higher dimensionality frameworks. Hypothetically, the uncharged trimer, isolated at $\mathrm{pH}$ 7.3, may exist in acidic aqueous solution as a positively charged species, by protonation of the basic groups. As it will be discussed below, this species is thought to play a key role in generating higher dimensionality frameworks of $\mathrm{Ca}-\mathrm{H}_{3} \mathrm{HPA}$ compounds. In fact, the metal-ligand connectivity appearing in the molecular trimer is preserved in the two-dimensional and three-dimensional solids.

Compound 2, $\mathrm{Ca}\left(\mathrm{HO}_{3} \mathrm{PCH}(\mathrm{OH}) \mathrm{COO}\right) \cdot 3 \mathrm{H}_{2} \mathrm{O}$, is obtained at room temperature, and it crystallizes in the orthorhombic system $P 2_{1} n b$ and contains 26 non-hydrogen atoms in the asymmetric unit: two calcium atoms, two $\mathrm{H}_{1} \mathrm{HPA}^{2-}$ ligands, and six water molecules, all of them located in general positions. Its structure, solved from laboratory X-ray powder diffraction data, corresponds to a layered framework. Figure 5a shows a trimeric unit $\mathrm{CaO}_{8}-\mathrm{CaO}_{6}-\mathrm{CaO}_{8}$ as building block of the hybrid layers where six-membered rings for the central octahedral calcium and five-membered rings for the side eightcoordinated calcium ions are evident. The organo-inorganic layer, Figure $5 b$, is composed of $\mathrm{CaO}_{6}$ octahedra and $\mathrm{CaO}_{8}$ polyhedra, with $\mathrm{Ca}-\mathrm{O}$ bond distances ranging from 2.20 (1) to 2.85(1) A. Within the layers, the same connectivity scheme observed in $\mathbf{1}$ is kept. Each distorted $\mathrm{CaO}_{6}$ octahedron is bonded to four phosphonate oxygens from four $\mathrm{H}_{1} \mathrm{HPA}^{2-}$ ligands and two oxygens from two carboxylate groups. The eight-coordinated $\mathrm{Ca}^{2+}$ center is bonded to four water molecules, and the remaining sites are occupied by two hydroxyl oxygen atoms and two carboxylate oxygen atoms from two $\mathrm{H}_{1} \mathrm{HPA}^{2-}$ ligands. Each carboxylate group bridges both $\mathrm{CaO}_{6}$ and $\mathrm{CaO}_{8}$ polyhedra in anti-anti mode, while the phosphonate group bridges two $\mathrm{CaO}_{6}$ octahedra, leaving a free $\mathrm{P}-\mathrm{OH}$ group pointing to the interlayer space. The remaining two noncoordinated water molecules (Ow5 and Ow6) are located in the interlayer space interacting by $\mathrm{H}$-bonding with the free $\mathrm{P}-\mathrm{OH}$ groups (see Table $\mathrm{S} 3$, Supporting Information). It is important to note that the layers are linked to each other only through van der Waals interactions, rather than by hydrogen bonds, because the distances between the lattice water molecules of a layer with the oxygen atoms of adjacent layer are longer than $3.5 \AA$ (see Figure $5 \mathrm{c}$ ).

These features provide insights into the $2 \mathrm{D}$ framework as being composed of interconnected protonated trimeric and monomeric units in a 1:1 ratio. The monomeric unit, formed by a $\mathrm{CaO}_{6}$ octahedron, resembles that of the central $\mathrm{Ca}$ in the trimer unit, so that the $\mathrm{CaO}_{6}-\mathrm{CaO}_{8}$ linkages are maintained unchanged along the network. Instead of the labile water molecules, the axial coordination sites of $\mathrm{CaO}_{6}$ octahedra are now occupied by phosphonate oxygens, increasing thus the connectivity of this moiety in the resulting two-dimensional framework. Interestingly, compound $\mathrm{Na}_{2}\left[\mathrm{Cd}_{2}\left\{\mathrm{O}_{3} \mathrm{PCH}(\mathrm{OH}) \mathrm{CO}_{2}\right\}_{2}\left(\mathrm{H}_{2} \mathrm{O}\right)_{3}\right] \cdot 2 \mathrm{H}_{2} \mathrm{O}$, prepared at $120^{\circ} \mathrm{C},{ }^{28}$ has a two-dimensional framework quite similar to that of compound 2. In this case, the hybrid layer is composed of 


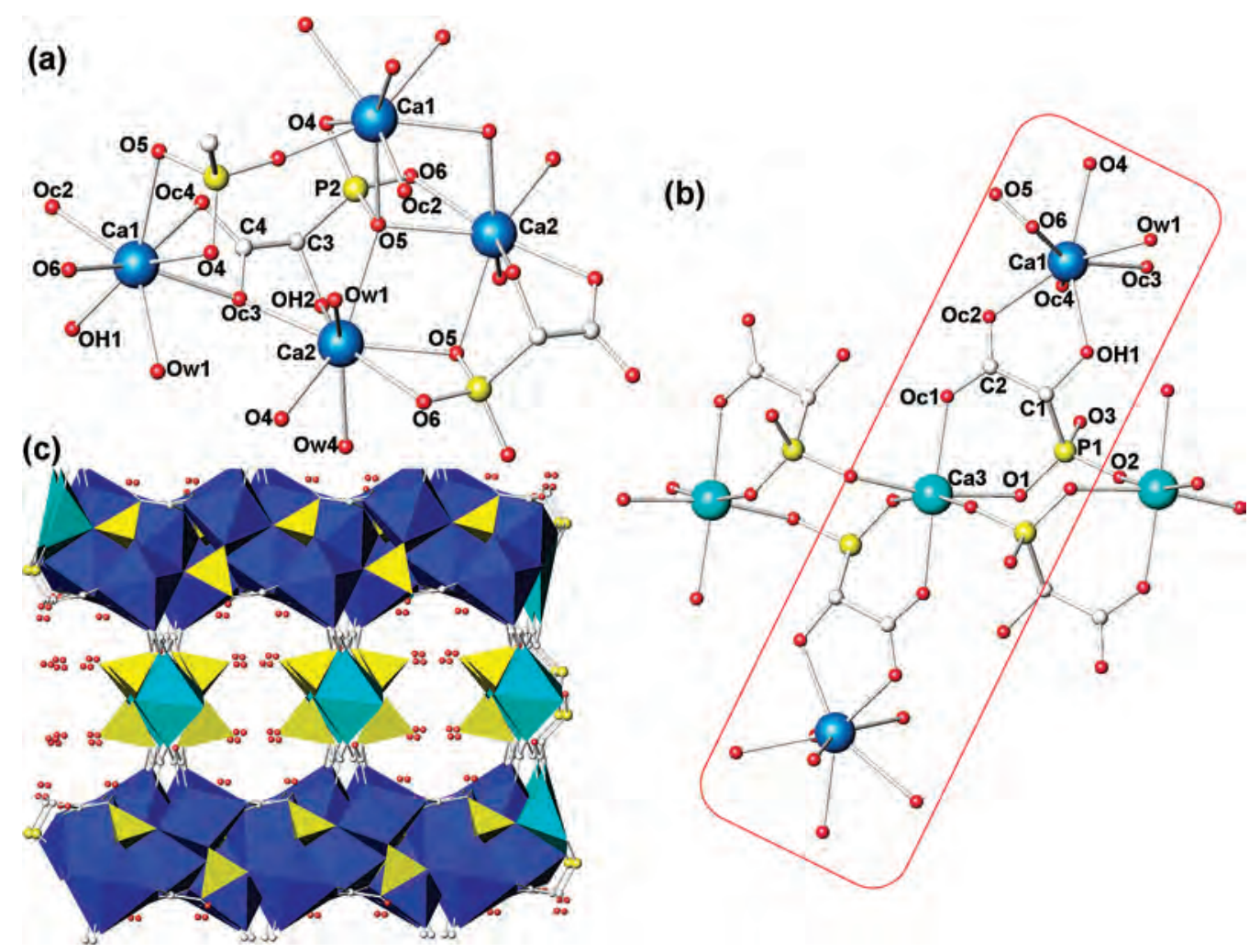

Figure 6. Crystal structure of $3, \mathrm{Ca}_{5}\left(\mathrm{O}_{3} \mathrm{PCHOHCOO}\right)_{2}\left(\mathrm{HO}_{3} \mathrm{PCHOHCOO}\right)_{2} \cdot 6 \mathrm{H}_{2} \mathrm{O}$. (a) Ball-stick representation (atoms labeled) showing the connectivity between $\mathrm{CaO}_{8}$ polyhedra and $\mathrm{HPA}^{3-}$ ligands to form the organo-inorganic sheets. (b) Ball-stick representation of the link between the layers highlighting the trimeric calcium inorganic moieties resulting in one-dimensional chains. (c) Polyhedral view, along the $c$-axis, of the 3D open framework. $\mathrm{CaO}_{6}$, sky-blue octahedra; $\mathrm{CaO}_{8}$, blue polyhedra; $\mathrm{CPO}_{3}$, yellow tetrahedra; $\mathrm{O}$, red balls.

alternating $\mathrm{CdO}_{6}$ octahedra and $\mathrm{CdO}_{7}$ polyhedra connected by $\mathrm{HPA}^{3-}$ anions, which maintain the same coordination pattern with respect to the metal ion, despite variations in the method of synthesis. Instead of $\mathrm{H}^{+}$, hydrated $\mathrm{Na}^{+}$ions are used to compensate the negative charge of the layer in the $\mathrm{Cd}^{2+}$ derivative. It is inferred, therefore, that similar building blocks are used to generate the $2 \mathrm{D}$ frameworks of both compounds, $\mathrm{CdO}_{7}-\mathrm{CdO}_{6}-\mathrm{CdO}_{7}$ trimers as common inorganic moieties for the cadmium derivative.

Compound 3, $\mathrm{Ca}_{5}\left(\mathrm{O}_{3} \mathrm{PCHOHCOO}\right)_{2}\left(\mathrm{HO}_{3} \mathrm{PCHOHCOO}\right)_{2}$. $6 \mathrm{H}_{2} \mathrm{O}$, prepared by a hydrothermal reaction, shows a complex structure with a large unit cell volume of $2968.76(7) \AA^{3}$. Its XRPD pattern was indexed in a body-centered monoclinic lattice, and the systematic absences were consistent with the space group $12 / a$. Its structure, solved $a b$ initio from synchrotron powder diffraction data, contains 25 non-hydrogen atoms in the asymmetric part of the unit cell. Its crystal structure may be viewed as composed of sheets of $\mathrm{CaO}_{8}$ polyhedra and deprotonated $\mathrm{HPA}^{3-}$ moieties separated by chains of $\mathrm{CaO}_{6}$ octahedra interconnected through $\mathrm{H}_{1} \mathrm{HPA}^{2-}$ ligands, which lead to a nonporous $3 \mathrm{D}$ open-framework, see Figure 6. This packing generates one-dimensional channels along the $c$-axis, being occupied by two disordered water molecules. A deeper insight into this 3D framework suggests that it may be built from the condensation of cationic trimeric inorganic bricks, $\left[\mathrm{Ca}_{3}\left(\mathrm{H}_{1} \mathrm{HPA}\right)_{2}\right]^{2+}$, with anionic monomeric species, such as $[\mathrm{Ca}(\mathrm{HPA})]^{-}$, which would facilitate the interconnection among the highly packed $\mathrm{CaO}_{8}$ polyhedra into the sheet.

The sheets contain two crystallographically independent $\mathrm{Ca}^{2+}$ atoms, $\mathrm{Ca} 1$ and $\mathrm{Ca} 2$, in eight-coordinated environments, with $\mathrm{Ca}-\mathrm{O}$ bond distances ranging from $2.25(1)$ to $2.61(1) \AA$.
Figure 6a shows the connectivity modes between $\mathrm{CaO}_{8}$ polyhedra and the $\mathrm{HPA}^{3-}$ ligands. $\mathrm{Cal}$ is bonded to three oxygens from two phosphonate groups, two oxygens from one carboxylate group, one oxygen from a second carboxylate group, the $\mathrm{OH}$ group $(\mathrm{OH} 1)$, and one water molecule (Ow1). Ca2 binds to four oxygens from three phosphonate groups and to two other oxygens from two carboxylate groups. The coordination is completed by the hydroxyl group $\mathrm{OH} 2$ and a water molecule (Ow1). Each Cal polyhedron is surrounded by three $\mathrm{Ca} 2$ polyhedra, sharing face, edge, and corner, while $\mathrm{Ca} 2$ polyhedra only share one edge among them. One of the oxygen atoms from the phosphonate group (O5) is triply coordinated to one $\mathrm{Ca} 1$ and two $\mathrm{Ca} 2$, whereas oxygen $\mathrm{O} 4$ and the two carboxylate oxygens, Oc3 and Oc4, are doubly coordinated, linking Cal and $\mathrm{Ca} 2$ polyhedra. Only oxygen $\mathrm{O} 6$ and the hydroxyl group $\mathrm{OH} 2$ are linked to one single metal center. This uncommonly high metal-ligand connectivity results in a closed packing into the sheet.

On the other hand, the chains linking adjacent sheets, see Figure $6 \mathrm{~b}$, are composed of slightly distorted $\mathrm{CaO}_{6}$ octahedra ( $\mathrm{Ca}-\mathrm{O}$ bond lengths between 2.27(1) and 2.41(1) $\AA$ ). Each octahedron is linked to four $\mathrm{H}_{1} \mathrm{HPA}^{2-}$ ligands and two oxygen atoms from two carboxylates (Oc1). Each $\mathrm{H}_{1} \mathrm{HPA}^{2-}$ ligand bridges two $\mathrm{Ca}$ centers through the oxygens $\mathrm{O} 1$ and $\mathrm{O} 2$, which allows the extension of the chains along the $c$-axis. The third phosphonate oxygen is protonated and remains unbound. The connection of the $\mathrm{CaO}_{6}$ octahedra to the sheets is arranged in the same way as the $\mathrm{CaO}_{6}-\mathrm{CaO}_{8}$ linkage in the molecular trimer, see Figure $6 \mathrm{~b}$. The resulting $1 \mathrm{D}$ channels are occupied by three 


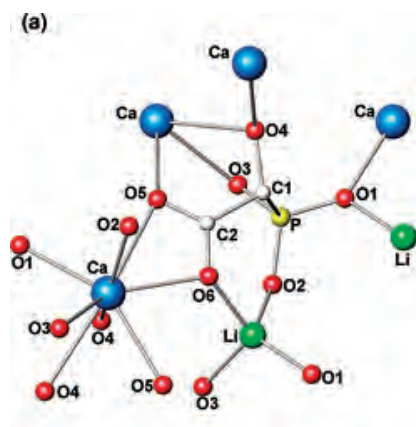

(b)

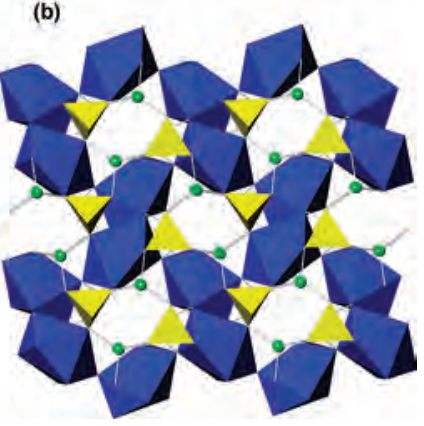

Figure 7. (a) Ball-stick view of the coordinated environment of calcium and lithium ions with atoms labeled for $4, \mathrm{CaLi}\left(\mathrm{O}_{3} \mathrm{PCHOHCOO}\right)$. (b) View, along the $c$-axis, of the $3 \mathrm{D}$ framework built from $\mathrm{CaO}_{8}$ polyhedra sharing corners. Ca, large blue spheres; $\mathrm{P}$, medium-size yellow spheres; $\mathrm{C}$, white balls; $\mathrm{O}$, red balls; $\mathrm{Li}$, green balls; $\mathrm{CPO}_{3}$, yellow tetrahedra; $\mathrm{CaO}_{8}$, blue polyhedra.

water molecules (Ow2, O3w, and Ow4), which strongly interact with each other through H-bonds $(\sim 2.54(1)-2.57(1) \AA)$. The water molecule Ow3 is disordered along the network and interacts with the $\mathrm{CaO}_{8}$ polyhedra by a $\mathrm{H}$-bond. The remaining two water molecules, Ow2 and Ow4, are localized at the center of the channels interacting by hydrogen bonds with the $\mathrm{H}_{1} \mathrm{HPA}^{2-}$ group of the chains, but Ow4 is disordered (see Table S4, Supporting Information). As revealed by the thermodiffractometry study, these hydration water molecules are completely removed at $260{ }^{\circ} \mathrm{C}$ without appreciable structural modification. Finally, 3 was activated at $240^{\circ} \mathrm{C}$, see above, in order to test its possible porous properties. Unfortunately, $\mathrm{N}_{2}$ and $\mathrm{CO}_{2}$ sorption isotherms gave a surface area close to $3 \mathrm{~m}^{2} \mathrm{~g}^{-1}$. Therefore, $\mathrm{Ca}_{5}\left(\mathrm{O}_{3} \mathrm{PCHOHCOO}\right)_{2}\left(\mathrm{HO}_{3} \mathrm{PCHOHCOO}\right)_{2} \cdot 2 \mathrm{H}_{2} \mathrm{O}$ did not display measurable porosity.

The lack of $\mathrm{Ca}-\mathrm{H}_{3} \mathrm{HPA}$ compounds with one-dimensional chains, analogous to other M(II) hydroxyphosphonoacetates, may also be indicative of the different behavior for the studied system. Likewise, one-dimensional chain compounds are lacking for $\mathrm{Cd}^{2+}$ derivatives, a behavior that is related to the similarity in size for both metal ions $\left[r\left(\mathrm{Ca}^{2+}\right)=0.99 \AA, r\left(\mathrm{Cd}^{2+}\right)=0.97 \AA\right]$. The metal-ligand coordination mode, characteristic of the trimeric inorganic moieties, is no longer present in $\mathrm{M}$ (II) derivatives of metal ions of larger ionic radius than $\mathrm{Ca}^{2+}$, such as $\mathrm{Sr}^{2+}$ and $\mathrm{Ba}^{2+}$. In such cases, reactions conducted at room temperature lead to two-dimensional $\left(\mathrm{Sr}^{2+}\right)$ or three-dimensional $\left(\mathrm{Ba}^{2+}\right)$ frameworks, as a result of the condensation of single monomeric eight-coordinated or nine-coordinated complex species, respectively. ${ }^{17}$

The presence of lithium ions in the reaction mixture, at $180^{\circ} \mathrm{C}$, led to the isolation of 4 with the stoichiometry $\mathrm{CaLi}$ $\left(\mathrm{O}_{3} \mathrm{PCHOHCOO}\right)$. The powder pattern of 4 was indexed in a triclinic unit cell, and its structure was solved from laboratory XRPD data following an ab initio methodology. The basic bonding scheme is given in Figure 7a. The framework is built from $\mathrm{CaO}_{8}$ polyhedra sharing corners and edges, with $\mathrm{Ca}-\mathrm{O}$ bond distances ranging between $2.29(1)$ and 2.74(1) $\AA$, and $\mathrm{Li}^{+}$ions in tetrahedral positions. Each $\mathrm{Li}^{+}$ion is bonded to three oxygens from three different deprotonated phosphonate groups $\left(\mathrm{HPA}^{3-}\right)$ and a fourth oxygen from a carboxylate group. $\mathrm{Li}-\mathrm{O}$ bond lengths range from $1.93(1)$ to $2.00(1) \AA . \mathrm{Ca}^{2+}$ is coordinated to three oxygens from three different $\mathrm{HPA}^{3-}$ ligands, one $\mathrm{OH}$ group from a fourth $\mathrm{HPA}^{3-}$ ligand, and four oxygens from two $\mathrm{HPA}^{3-}$ bidentate ligands. The $3 \mathrm{D}$ framework of $\mathbf{4}$ is displayed in
Figure $7 \mathrm{~b}$ with small channels running along the $c$-axis. However, porosity is not expected for this solid due to the quite small size of these channels.

Compound 5, $\mathrm{Ca}_{2} \mathrm{Na}\left(\mathrm{O}_{3} \mathrm{PCHOHCOO}\right)\left(\mathrm{HO}_{3} \mathrm{PCHOH}\right.$ $\mathrm{COO}) \cdot 1.5 \mathrm{H}_{2} \mathrm{O}$, was obtained when the reaction was conducted at $180^{\circ} \mathrm{C}$ in the presence of $\mathrm{Na}^{+}$, added as $\mathrm{NaOH}$ to increase the initial $\mathrm{pH}$ in the range 2.0-7.2. Single-crystal diffraction studies of plate-shaped crystals of $\mathbf{5}$ revealed that this compound crystallizes in the triclinic space group $P \overline{1}$. The content of the asymmetric unit is given in Figure 8a. The structure of 5 can be envisaged as a pillared framework built from negatively charged inorganic layers of calcium polyhedra and phosphonate groups, with $\mathrm{Na}^{+}$as charge-compensating cations (see Figure $8 \mathrm{~b}$ ). The free space left between pillars is occupied by water molecules. The organo-inorganic layer is formed by corrugated chains of alternated $\mathrm{CaO}_{7}$ and $\mathrm{CaO}_{6}$ dimers sharing edges (see Figure $8 \mathrm{c}$ ). The $\mathrm{Ca}-\mathrm{O}$ bond lengths range between 2.31(1) and 2.60(1) $\AA$. Seven-coordinated $\mathrm{Ca}^{2+}$ (Ca1) is surrounded by four oxygens from three $\mathrm{HPA}^{3-}$ anions, two of them arising from a bidentate group, two oxygen from other two $\mathrm{H}_{1} \mathrm{HPA}^{2-}$, and an oxygen atom from the carboxylate group. Six-coordinated $\mathrm{Ca}^{2+}(\mathrm{Ca} 2)$ is surrounded by a strongly distorted octahedral environment of oxygens, and it is linked to five phosphonate groups, two $\mathrm{H}_{1} \mathrm{HPA}^{2-}$ and three $\mathrm{HPA}^{3-}$ anions. One of the latter species acts as a chelate and preserves the coordination mode, $\mathrm{Ca}-\mathrm{O}-\mathrm{P}-\mathrm{C}-\mathrm{C}-\mathrm{O}-\mathrm{Ca}$ six-membered ring, of $\mathbf{1}$ and 2 , reminiscent of the primitive building blocks used to generate these compounds. The sixth position is occupied by one carboxylate oxygen. One oxygen atom from each phosphonate groups, $\mathrm{O} 1$ and $\mathrm{O} 7$, respectively, bridges two adjacent metal centers thus making possible edge sharing between $\mathrm{CaO}_{7}-\mathrm{CaO}_{6}$ polyhedra. Edge sharing of the coordination polyhedra is carried out through the oxygen atoms $\mathrm{O} 3$ from two $\mathrm{HPA}^{3-}$ ligands $\left(\mathrm{CaO}_{6}\right.$ dimers) or through the oxygen atoms $\mathrm{O} 6$ from two $\mathrm{H}_{1} \mathrm{HPA}^{2-}$ ligands $\left(\mathrm{CaO}_{7}\right.$ dimers $)$. The protonated oxygen, $\mathrm{O} 5$, from the phosphonate group is only coordinated to Cal.

The carboxylate and hydroxyl groups of both $\mathrm{H}_{1} \mathrm{HPA}^{2-}$ and $\mathrm{HPA}^{3-}$ groups are pointing toward the interlayer region to interact with the $\mathrm{Na}^{+}$ions. The carboxylate group of the $\mathrm{H}_{1} \mathrm{HPA}^{3--}$ ligand acts as a bidentate ligand for $\mathrm{Na}^{+}$ions, through the oxygens $\mathrm{O} 22$ and $\mathrm{O} 23$, with bond distances of 2.75(1) and 2.40 (1) $\AA$, respectively. The carboxylate group from the $\mathrm{HPA}^{3-}$ ligand binds simultaneously to $\mathrm{Ca}^{2+}$ and $\mathrm{Na}^{+}$ions, through the oxygen $\mathrm{O} 13$ to $\mathrm{Cal}$ and through the oxygen $\mathrm{O} 12$ to two $\mathrm{Na}^{+}$ ions. The seven-coordinated environment around $\mathrm{Na}^{+}$cations is completed by both hydroxyl groups and a water molecule, O1w. The second water molecule, $\mathrm{O} 2 \mathrm{w}$, is disordered within the narrow one-dimensional channels that appear between the pillars. In these channels, the water molecule establishes strong $\mathrm{H}$-bonds with the oxygen from both carboxylate groups and with the oxygen atoms belonging to the hydroxyl group (O21), beside others longer interactions (see Table S5, Supporting Information).

Although both $\mathrm{Ca}^{2+}$ and $\mathrm{Cd}^{2+}$ have relatively similar structure-directing behavior, the crystal structure of $\mathbf{5}$ is different from that of the heterometallic sodium-cadmium hydroxyphosphonoacetate $\mathrm{Na}_{2}\left[\mathrm{Cd}_{2}\left\{\mathrm{O}_{3} \mathrm{PCH}(\mathrm{OH}) \mathrm{CO}_{2}\right\}_{2}\left(\mathrm{H}_{2} \mathrm{O}\right)_{3}\right] \cdot 2 \mathrm{H}_{2} \mathrm{O}$. This may be tentatively explained in terms of the presence/absence of the trimer species as basic inorganic bricks. The more drastic experimental conditions employed for the synthesis of the $\mathrm{Na}-\mathrm{Ca}$ derivative were sufficient to disrupt formation of the $\mathrm{Ca}_{3}$ trimer and generate two new dimeric inorganic moieties. 


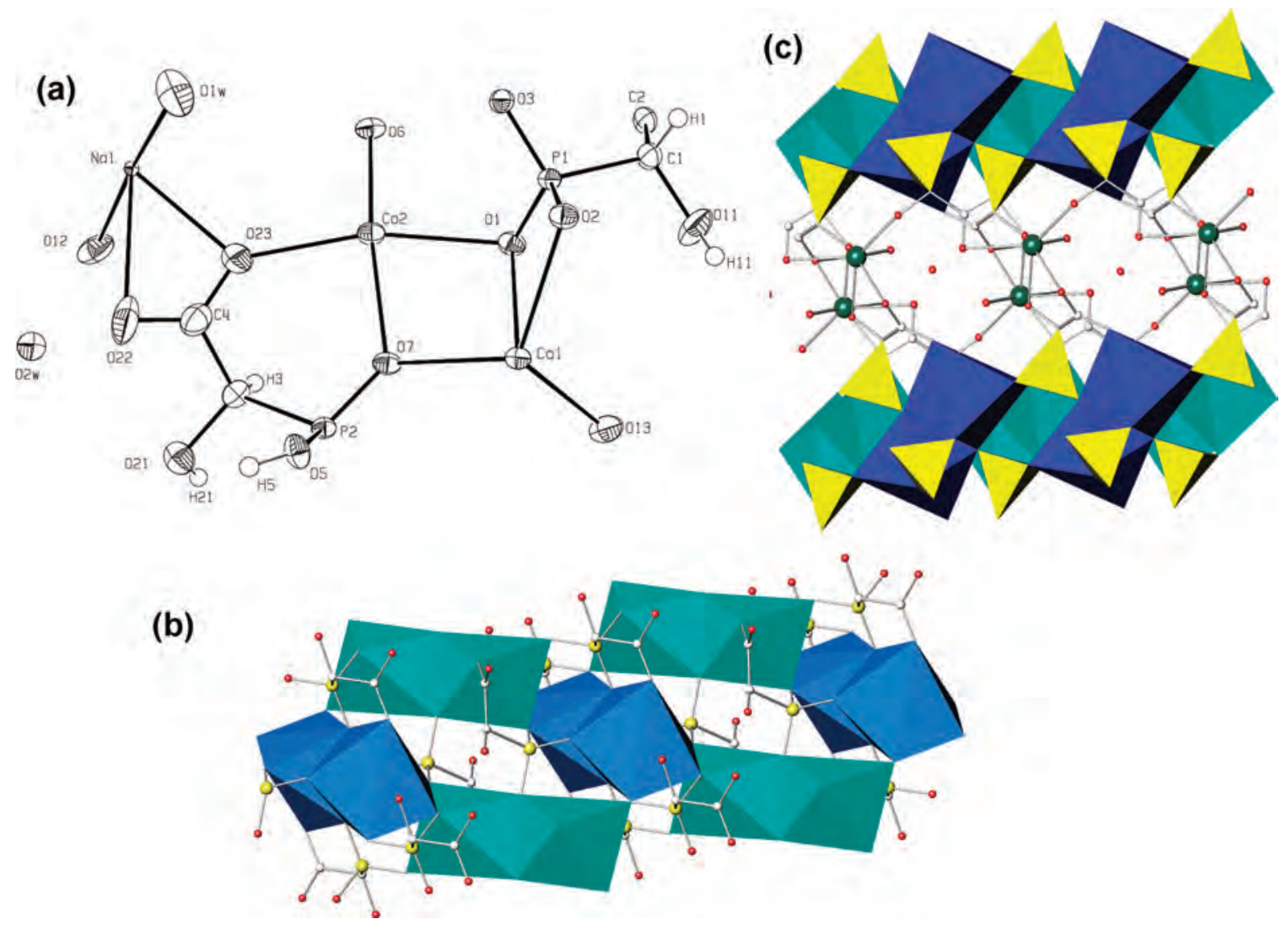

Figure 8. Crystal structure of $5, \mathrm{Ca}_{2} \mathrm{Na}\left(\mathrm{O}_{3} \mathrm{PCHOHCOO}\right)\left(\mathrm{HO}_{3} \mathrm{PCHOHCOO}\right) \cdot 1.5 \mathrm{H}_{2} \mathrm{O}$. (a) Asymmetric unit with the atoms labeled and the thermal ellipsoids shown at the $50 \%$ probability level. (b) Framework (polyhedra and ball-stick representation) along [010]. (c) Hybrid layer with chains of alternated $\mathrm{CaO}_{7}$ and $\mathrm{CaO}_{6}$ dimers. $\mathrm{P}$, medium-size yellow spheres; $\mathrm{C}$, white balls; $\mathrm{O}$, red balls; $\mathrm{Na}$, green balls; $\mathrm{CaO}_{6}$, shy-blue polyhedra; $\mathrm{CaO}$, blue polyhedra; $\mathrm{CPO}_{3}$, yellow tetrahedra; $\mathrm{H}$ atoms not shown for clarity.

There is also the possibility that the $\mathrm{Na}-\mathrm{Cd}$ derivative is a sort of transient phase, resulting from a simple ion exchange of $\mathrm{H}^{+}$for $\mathrm{Na}^{+}$occurring in the framework of 2 , which then transforms into a new one, $\mathbf{5}$, at higher temperature. In that case, a sodium-calcium hydroxyphosphonoacetate framework equivalent to that of the $\mathrm{Na}-\mathrm{Cd}$ derivative may be anticipated to exist. Conversely, compounds of the isomorphous series $\mathrm{NaM}\left\{\mathrm{O}_{3} \mathrm{PCH}(\mathrm{OH}) \mathrm{CO}_{2}\right\}$ $(\mathrm{M}=\mathrm{Mg}, \mathrm{Mn}, \mathrm{Fe}, \mathrm{Co}, \mathrm{Zn})^{13 a, 14 a}$ show a completely different $2 \mathrm{D}$ pillared framework with mixed layers built from $\mathrm{MO}_{6}$ octahedra and $\mathrm{NaO}_{5}$ pyramids sharing edges and corners, the $\mathrm{Na} / \mathrm{MO}$ sheets being connected by $\mathrm{HPA}^{3-}$ groups. ${ }^{13 a}$

Finally, the five $\mathrm{Ca}-\mathrm{H}_{3} \mathrm{HPA}$ crystal structures reported here are the first ones of this system. It is worth noting that there is a review dealing with alkaline earth metal phosphonates and carboxyphosphonates. ${ }^{8}$ There are several calcium carboxylate and phosphonate derivatives, but next we discuss the crystal structures of two calcium carboxyphosphonates. The structure of calcium 2-phosphonobutane-1,2,4-tricarboxylate (Ca-PBTC) contains $\mathrm{CaO}_{7}$ polyhedra arranged in zigzag chains. ${ }^{31}$ It is worth pointing out that the six-membered ring previously discussed in this paper is also present in Ca-PBTC. On the other hand, the crystal structure of calcium carboxymethylphosphonate contains infinite chains of $\mathrm{CaO}_{8}$ polyhedra sharing edges, from oxygen of the phosphonates groups. These chains are located within the inorganic layers with the carboxylate groups pointing toward the interlayer space. $^{32}$

\section{CONCLUSIONS}

Herein, we described our recent efforts to structurally map the area of metal carboxyphosphonate hybrid materials, by systematically studying the structural motifs observed in products of the calcium-hydroxyphosphonoacetate system. The main findings of this study are outlined below:

(1) Temperature plays a significant role in the outcome of the synthesis. In general, low-temperature syntheses (usually RT) lead to formation of less dense solids.

(2) The presence of added small alkali metal ions $\left(\mathrm{Li}^{+}, \mathrm{Na}^{+}\right)$ cause significant structural changes in the resulting products. The resulting solids are much denser due to a higher dimensionality of the frameworks.

(3) The reaction medium $\mathrm{pH}$ is an important determinant of the deprotonation state of hydroxyphosphonoacetic acid and, hence, of the metal $-\mathrm{H}_{3} \mathrm{HPA}$ products obtained. As expected, syntheses in low $\mathrm{pH}$ regions $(<4)$ result in the incorporation of the bis-deprotonated ligand into the final framework. Higher $\mathrm{pH}$ syntheses $(>4)$ lead to formation of materials where the ligand exists in its trideprotonated state. There seems to be a direct relationship of ligand deprotonation and formation of "dense", 3D structures.

(4) A key structural finding shows that a trimeric inorganic moiety, " $\mathrm{Ca}_{3}\left(\mathrm{O}_{3} \mathrm{PCH}(\mathrm{OH}) \mathrm{CO}_{2}\right)_{2}$ " is a recurring structural brick present in the structures of all the $\mathrm{Ca}-\mathrm{H}_{3} \mathrm{HPA}$ hybrids described herein. $\mathrm{HPA}^{3-}$ ligands bond a central 
octahedral $\mathrm{Ca}^{2+}$ through two pairs of oxygen atoms from the carboxylate and phosphonate groups forming two sixmembered rings, $\mathrm{Ca}-\mathrm{O}-\mathrm{C}-\mathrm{C}-\mathrm{P}-\mathrm{O}-\mathrm{Ca}$. This local arrangement allows the two external octacoordinated $\mathrm{Ca}^{2+}$ ions to bind the ligand through the $\mathrm{OH}$ group and the other carboxylate oxygen, forming a five-membered ring, $\mathrm{Ca}-\mathrm{O}-\mathrm{C}-\mathrm{C}-\mathrm{O}-\mathrm{Ca}$. Efforts to broaden the synthetic utility of the novel " $\mathrm{Ca}_{3}\left(\mathrm{O}_{3} \mathrm{PCH}\right.$ $\left.(\mathrm{OH}) \mathrm{CO}_{2}\right)_{2}$ ” brick are currently underway in our laboratories.

\section{ASSOCIATED CONTENT}

S Supporting Information. CIF files for all new structures, a photograph of the high-throughput system used, the thermodiffractometric study for 3, X-ray powder diffraction Rietveld plots for 2, 3, and 4, some selected synthesis parameters for the high-throughput preparations, and $\mathrm{H}$-bond network details for $\mathbf{1}$, 2,3 , and 5 . This material is available free of charge via the Internet at http://pubs.acs.org.

\section{AUTHOR INFORMATION}

\section{Corresponding Author}

*E-mail address: g_aranda@uma.es.

\section{ACKNOWLEDGMENT}

ESRF is thanked for the provision of X-ray synchrotron powder diffraction beam time. The work at UMA was funded by MAT2009-07016 and MAT2010-15175 research grants (MICINN, Spain). The work at UOC was funded by the Special Research Account (ELKE), project KA 2573. The project "Factoría de Crystalización, CONSOLIDER INGENIO-2010" is acknowledged for providing single-crystal X-ray diffraction facilities.

\section{REFERENCES}

(1) Cheetham, A. K.; Rao, C. N. R.; Fellera, R. K. Chem. Commun. 2006, 4780-4795.

(2) (a) Clearfield, A. Curr. Opin. Solid State Mater. Sci. 2002, 6, 495-506. (b) Rowsell, J. L.C.; Yaghi, O. M. Microporous Mesoporous Mater. 2004, 73, 3-14. (c) Rosseinsky, M. J. Microporous Mesoporous Mater. 2004, 73, 15-30. (d) Rao, C. N. R.; Natarajan, S.; Vaidhyanathan, R. Angew. Chem., Int. Ed. 2004, 43, 1466-1496. (e) Long, J. R; Yaghi, O. M. Chem. Soc. Rev. 2009, 38, 1203-1212.

(3) O'Keeffe, M. Chem. Soc. Rev. 2009, 38, 1215-1217.

(4) Li, J. R.; Kuppler, R. J.; Zhou, H. C. Chem. Soc. Rev. 2009, $38,1477-1504$.

(5) Murray, L. J.; Dinca, M.; Long, J. R. Chem. Soc. Rev. 2009, 38, 1294-1314.

(6) Lee, J. Y.; Farha, O. K.; Roberts, J.; Scheidt, K. A.; Nguyen, S. T.; Hupp, J. T. Chem. Soc. Rev. 2009, 38, 1450-1459.

(7) Allendorf, M. D.; Bauer, C. A.; Bhakta, R. K.; Houk, R. J. T. Chem. Soc. Rev. 2009, 38, 1330-1352.

(8) (a) Stock, N.; Bein, T. Angew. Chem., Int. Ed. 2004, 43, 749-752. (b) Colodrero, R. M. P.; Cabeza, A.; Olivera-Pastor, P.; Infantes-Molina, A.; Barouda, E.; Demadis, K. D.; Aranda, M. A. G. Chem.-Eur. J. 2009, 15, 6612-6618. (c) Gómez-Alcantara, M. M.; Aranda, M. A. G.; OliveraPastor, P.; Beran, P.; García-Muñoz, J. L.; Cabeza, A. Dalton Trans. 2006, 577-585. (d) Maeda, K. Microporous Mesoporous Mater. 2004, 73, 47-55. (e) Sharma, C. V. K.; Clearfield, A.; Cabeza, A.; Aranda, M. A. G.; Bruque, S. J. Am. Chem. Soc. 2001, 123, 2885-2886. (f) Miller, S. R.; Pearce, G. M.; Wright, P. A.; Bonino, F.; Chavan, S.; Bordiga, S.;
Margiolaki, I.; Guillou, N.; Férey, G.; Bourrelly, S.; Llewellyn, P. L. J. Am. Chem. Soc. 2008, 130, 15967-15981.(g) Demadis, K. in Progress in Solid State Chemistry Research, Buckley, R. W., Ed.; Nova Science Publishers, Inc.: New York, 2007; pp 109-172.

(9) (a) Cui, L.; Sun, Z.; Chen, H.; Meng, L.; Dong., D.; Tian, C.; Zhu, Z.; You, W. J. Coord. Chem. 2007, 60, 1247-1254. (b) Zhu, Y.-Y.; Li, J.; Sun, Z.-G.; Zhang, J.; Zhao, Y.; Lu, X.; Liu, L.; Zhang, N. Z. Anorg. Allg. Chem. 2009, 635, 171-174. (c) Liu, L.; Li, J.; Sun, Z.-G.; Dong, D.-P.; Zhang, N.; Lu, X.; Wang, W.-N.; Tong, F. Z. Anorg. Allg. Chem. 2010, 636, 247-252. (d) Fu, R.; Hu, S.; Wu, X. Dalton Trans. 2009, 9843-9848.

(10) Dong, D.-P.; Li, J.; Sun, Z.; Zheng, X.; Chen, H.; Meng, L.; Zhu, Y.; Zhao, Y.; Zhang, J. Inorg. Chem. Commun. 2007, 10, 1109-1112.

(11) (a) Demadis, K. D.; Papadaki, M.; Císarova, I. Appl. Mater. Interfaces 2010, 2, 1814-1816. (b) Papadaki, M.; Demadis, K. D. Comments Inorg. Chem. 2009, 30, 89-118.

(12) Clearfield, A. Dalton Trans. 2008, 6089-6102.

(13) (a) Lai, Z.; Fu, R.; Hu, S.; Wu, X. Eur. J. Inorg. Chem. 2007, 5439-5446. (b) Zhu, Y.; Sun, Z.; Zhao, Y.; Zhang, J.; Lu, X.; Zhang, N.; Liu, L.; Tong, F. New J. Chem. 2009, 33, 119-124. (c) Mao, J.-G. Coord. Chem. Rev. 2007, 251, 1493-1520.

(14) (a) Colodrero, R. M. P.; Olivera-Pastor, P.; Cabeza, A.; Papadaki, M.; Demadis, K. D.; Aranda, M. A. G. Inorg. Chem. 2010, 49, 761-768. (b) Demadis, K. D.; Papadaki, M.; Aranda, M. A. G.; Cabeza, A.; Olivera-Pastor, P.; Sanakis, Y. Cryst. Growth Des. 2010, $10,357-364$.

(15) (a) Forster, P. M.; Stock, N.; Cheetham, A. K. Angew. Chem., Int. Ed. 2005, 44, 7608-7611. (b) Sonnauer, A; Stock, N. Eur. J. Inorg. Chem. 2008, 5038-5045.

(16) Fu, R.; Zhang, H.; Wang, L.; Hu, S.; Li, Y.; Huang, X.; Wu, X. Eur. J. Inorg. Chem. 2005, 3211-3213.

(17) (a) Demadis, K. D.; Papadaki, M.; Raptis, R. G.; Zhao, H. Chem. Mater. 2008, 20, 4835-4846. (b) Demadis, K. D.; Papadaki, M.; Raptis, R. G.; Zhao, H. J. Solid State Chem. 2008, 181, 679-683.

(18) Boultif, A.; Louer, D. J. Appl. Crystallogr. 2004, 37, 724-731.

(19) Altomare, A.; Camalli, M.; Cuocci, C.; Giacovazzo, C.; Moliterni, A.; Rizzi, R. J. Appl. Crystallogr. 2009, 42, 1197-1202.

(20) Rius, J.; Sañé, J.; Miravitlles, C.; Amigó, J. M.; Reventós, M. M.; Louër, D. An. Quim. Int. Ed. 1996, 92, 223-227.

(21) Rius, J. Acta Crystallogr., Sect. A 2011 in press.

(22) Rietveld, H. M. J. Appl. Crystallogr. 1969, 2, 65-71.

(23) (a) Toby, B. H. J. Appl. Crystallogr. 2001, 34, 210-221.(b)

Larson, A. C.; von Dreele, R. B. Los Alamos National Laboratory, Report No. LA-UR-86-748, 2000.

(24) Bruker APEX2 Software, V2010.9-1, Bruker AXS Inc., Madison, Wisconsin, USA, 2005.

(25) Sheldrick, G. M. SADABS, Program for Empirical Absorption Correction of Area Detector Data, University of Göttingen, Germany, 1997.

(26) Sheldrick, G. M. Acta Crystallogr. 1990, A46, 467.

(27) Sheldrick, G. M. SHELXL-97, Program for the Refinement of Crystal Structures, University of Gottingen, Germany, 1997.

(28) Fu, R.; Hu, S.; Wu, X. Dalton Trans. 2009, 9440-9445.

(29) Sun, Z.; Chen, H.; Liu, Z.; Cui, L.; Zhu, Y.; Zhao, Y.; Zhang, J.; You., W.; Zhu, Z. Inorg. Chem. Commun. 2007, 10, 283-286.

(30) Fu, R.; Hu, S.; Wu, X. Dalton Trans. 2009, 9843-9848.

(31) Demadis, K. D.; Lykoudis, P.; Raptis, R. G.; Mezei, G. Cryst. Growth Des. 2006, 6, 1064-1067.

(32) Slepokura, K.; Lis, T. Acta Crystallogr., Sect. C 2003, $59, \mathrm{~m} 76-\mathrm{m} 78$. 